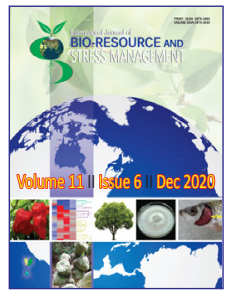

\title{
Response of Groundnut (Arachis hypogaea L.) to Lime and Different Levels of Sulphur
}

\author{
Imnatemjen Aier and D. Nongmaithem ${ }^{*}$
}

Dept. of Agronomy, SASRD: Nagaland University, Medziphema, Nagaland (797 106), India

\begin{abstract}
Open Access
Corresponding Author

D. Nongmaithem

e-mail: debikanong@gmail.com

Citation: Aier and Nongmaithem, 2020. Response of Groundnut (Arachis hypogaea L.) to Lime and Different Levels of Sulphur. International Journal of Bio-resource and Stress Management 2020, 11(6), 585589. HTTPS://DOI.ORG/10.23910/1.2020.2162a.

Copyright: (c) 2020 Aier and Nongmaithem. This is an open access article that permits unrestricted use, distribution and reproduction in any medium after the author(s) and source are credited.

Data Availability Statement: Legal restrictions are imposed on the public sharing of raw data. However, authors have full right to transfer or share the data in raw form upon request subject to either meeting the conditions of the original consents and the original research study. Further, access of data needs to meet whether the user complies with the ethical and legal obligations as data controllers to allow for secondary use of the data outside of the original study.
\end{abstract}

Conflict of interests: The authors have declared that no conflict of interest exists.

\begin{abstract}
A field experiment was conducted in the Experimental Research Farm of School of Agricultural Sciences and Rural Development (SASRD), Nagaland University during the kharif season 2018. Groundnut variety ICGS-76 was sown @ 70 kg $\mathrm{ha}^{-1}$ for $60 \times 20 \mathrm{~cm}^{2}$ spacing. The experiment was laid in split plot design with three replications. The main plot treatments consisted of two lime levels: lime @ $0 \mathrm{t} \mathrm{ha}^{-1}$ and lime @ $3 \mathrm{t} \mathrm{ha}^{-1}$ while the sub- plot treatments consisted of five sulphur levels: sulphur @ (0 kg ha-1, $10 \mathrm{~kg} \mathrm{ha}^{-1}, 20 \mathrm{~kg} \mathrm{ha}^{-1}, 30 \mathrm{~kg} \mathrm{ha}^{-1}$ and $40 \mathrm{~kg}$ $\mathrm{ha}^{-1}$ along with recommended dose of fertilizer at 20:60:40 kg N, $\mathrm{P}_{2} \mathrm{O}_{5}$ and $\mathrm{K}_{2} \mathrm{O}$ $\mathrm{ha}^{-1}$ respectively in the form of diammonium phosphate and murate of potash. The results showed that application of lime @ $3 \mathrm{t} \mathrm{ha}^{-1}$ gave higher growth and yield attributes compared to no lime and also application of sulphur @ 40 kg ha $^{-1}$ gave higher growth and yield attributes compared to lower doses of sulphur though there was only slight increase in the attributes between each successive doses of sulphur. Overall application of lime and sulphur increased all the yield attributes of groundnut, where the highest number of pods plant ${ }^{-1}$, seeds pod $^{-1}$, 100 kernels weight, pod yield, kernel yield and stover yield were recorded when treatment was done with lime @ 3 t ha ${ }^{1}$ and sulphur @ 40 kg ha $^{-1}$.
\end{abstract}

Keywords: Groundnut, lime, sulphur

\section{Introduction}

Groundnut cultivation is getting popularity among the farmers of NorthEastern Hill Region. There is ample scope to increase its productivity under upland conditions of mid-hills. Rice, maize and potato are the main crops of this region. Groundnut which on being recently introduced in the North Eastern region, is very likely to be grown widely across the region and the crop can also act as stand-in incase upland rice and maize proves uneconomical or it can be grown as an intercrop with upland rice and maize for higher productivity and return (Panwar et al., 2003). In Nagaland, Groundnut is grown in area of 930 ha producing 960 MT and yield of about $1032 \mathrm{~kg} \mathrm{ha}^{-1}$ (Nagaland economic survey 2015-2016).

The global production and use of synthetic nitrogenous fertilizers had increased considerably since 1960, which resulted in a significant increase in crop production and severe negative environmental and agronomic consequences for soil health, e.g., nitrate-N leaching and soil acidification (Smil, 2002). Acid soils are considered soils with a $\mathrm{pH}$ $<5.5$ in their surface horizons $(0-20 \mathrm{~cm})$. About 3950 million hectares

Article History

RECEIVED in $28^{\text {th }}$ October 2020 RECEIVED in revised form $12^{\text {th }}$ December 2020 ACCEPTED in final form $28^{\text {th }}$ December 2020 
of land area has been estimated to be affected by acidity, occupying nearly $30 \%$ of the global land surface (Sumner and Noble, 2003) and accounting for approximately 50\% of the global arable land area (Dai et al., 2017). Soil acidity is one of the most yield limiting factors that affect crop productivity (McLaren and Cameron, 1996; Sumner and Noble, 2003; Fageria and Nascente, 2014). Among the major constraints in crop production particularly in north eastern region of India, one of the factors hindering efficient fertilizer management is acidic soil. In India, about one-third of the cultivated land is affected by soil acidity (Mandal, 1997). Most of these soils are concentrated in north-east region of India, with nearly $65 \%$ of its area being under high level of soil acidity $(<5.5 \mathrm{pH})$ (Sharma and Singh, 2002). Groundnut can be grown on many soil types including those that are highly weathered and acidic (Gascho et al., 1993). However, the preferred $\mathrm{pH}$ for growing of groundnut is a $\mathrm{pH}$ of (6.5-7) which is slightly acidic or neutral. So for the crop to grow in a favorable soil $\mathrm{pH}$, liming is required. Every crop requires a preferred $\mathrm{pH}$ level in the soil so it can grown properly this adjustment in $\mathrm{pH}$ levels can be done by liming when the soil is acidic. Lime application along with integrated nutrient management is often recommended to increase the phyto-availability of essential nutrients and ameliorate the other acidity-induced fertility constraints on such soils (Haynes, 1984; Kumar et al., 2012). Liming also helps increase the nutrient availability, improves the soil structure and also increases the rate of infiltration. Management of soil acidity and improvement on productivity of crop on such soils therefore proves to be important in strengthening food security globally and regionally.

Development of modern agricultural technology has attracted the attention of scientists on sulphur nutrition owing to cultivation of high yielding varieties, adoption of intensive cropping systems particularly involving oil seeds and pulses, use of high analysis fertilizers and decreased usage of organic manures (Jaggi, 2004). Indian groundnut sellers and processors are steadily growing aware and concern for the quality of groundnut. Arranging and categorizing according to quality are becoming a practice. Indian manufacturer have the means to prepare and supply edible groundnuts conforming to highest standards. Among the various factors known to determine the groundnut yield and quality, balanced nutrition is an essential and basic factor contributing to high yield. Groundnut being an oilseed crop requires fertilization for high crop production. The farmers though aware of the fertilization in crops, are confined mostly in NPK fertilizers and negligence especially in sulphur fertilizer is common, however sulphur in oilseed crop is one of the key elements required to produce protein, oil and flavored compounds as well as to ensure quality, it is increasingly being recognised as the fourth major nutrient after nitrogen, phosphorus and potassium (Tandon and Messick, 2002). Sulphur is an important element for oil synthesis and formation of sulphur containing amino acids. It is the master nutrient for oilseed production as each unit of sulphur fertilizer generates 3-5 units of edible oil. In oilseeds sulphur plays a vital role in the development of seed and improving the quality (Naser et al., 2012). Sulphur helps in the synthesis of cysteine, methionine, chlorophyll, vitamins ( $B$, biotin and thiamine), metabolism of carbohydrates, oil content, protein content and also associated with growth and metabolism, especially by its effect on the proteolytic enzymes (Najar et al., 2011). Sulphur is identified as a key element for increasing the production of oilseeds by increasing the uptake of various macro and micronutrients in groundnut (Singh, 1999). Sulphur deficiency results in poor flowering, fruiting, cupping of leaves, reddening of stems, petiole and stunted growth. Since groundnut is rich both in oils and protein, requirement of sulphur for this crop is substantial high. Sulphur improves the chlorophyll, nodulation, increases the availability of other nutrients (Singh, 2007).

\section{Materials and Methods}

\subsection{Study site}

Experimental Research Farm, School of Agricultural Sciences and Rural Development (SASRD), Nagaland University, Medziphema, Nagaland.

\subsection{Treatment details}

The experiment comprised of two lime and five levels of sulphur, viz. lime @ 0 t ha ${ }^{-1}$ and 3 t ha-1 and Sulphur @ 0,10 , 20, 30 and 40) $\mathrm{kg} \mathrm{ha}^{-1}$ respectively. The experiment was laid out by adopting Split Plot Design (SPD) with three replications.

\subsection{General information}

Groundnut variety ICGS-76 was sown @ $70 \mathrm{~kg} \mathrm{ha}^{-1}$ for $60 \times 20$ $\mathrm{cm}^{2}$ spacing. Kernel treatment was done with carbendazime @ $2 \mathrm{~g} \mathrm{~kg}^{-1}$ of kernel. The soil was sandy loam and strongly acidic in reaction $(\mathrm{pH} 4.5)$. The soil contained $1.81 \%$ oxidizable organic carbon, $275 \mathrm{~kg} \mathrm{ha}^{-1}$ available nitrogen, $16.2 \mathrm{~kg} \mathrm{ha}^{-1}$ available phosphorus and $180.46 \mathrm{~kg} \mathrm{ha}^{-1}$ available potassium. Recommended dose of fertilizer at 20:60:40 kg N, $\mathrm{P}_{2} \mathrm{O}_{5}$ and $\mathrm{K}_{2} \mathrm{O} \mathrm{ha}{ }^{-1}$ respectively were applied in the form of diammonium phosphate and murate of potash at the time of sowing.

\subsection{Data collection}

For determining the vegetative growth characters, five plants from each plot were randomly selected and tagged excluding the border rows. Total numbers of pods were counted from five randomly selected plants and the average number of pods plant $^{-1}$ was worked out.

\subsection{Data analysis}

The data obtained are analyzed statistically by analysis of variance (F-test) as per the methods recommended by Gomez and Gomez (1984). The critical difference (CD) at 0.05 level of probability was calculated.

\section{Results and Discussion}

\subsection{Effect of lime and levels of sulphur on growth attribute of groundnut at different days of sowing.}

The data recorded in Table 1 shows that application of lime and sulphur levels influenced a significant variation in plant 


\begin{tabular}{|c|c|c|c|c|c|c|c|}
\hline \multirow[t]{3}{*}{ Treatments } & \multicolumn{3}{|c|}{ Plant height } & \multicolumn{2}{|c|}{ Crop growth rate $\left(\mathrm{g} \mathrm{m}^{-2} \mathrm{~d}^{-1}\right)$} & \multicolumn{2}{|c|}{ Relative growth rate $\left(\mathrm{g} \mathrm{g}^{-1} \mathrm{~d}^{-1}\right.$} \\
\hline & 30 & 60 & At & $30-60$ & 60 DAS & $30-60$ & 60 DAS \\
\hline & DAS & DAS & harvest & DAS & At harvest & DAS & At harvest \\
\hline \multicolumn{8}{|l|}{ Lime levels } \\
\hline $\mathrm{L}_{0}$ : lime @ 0 kg ha-1 & 16.58 & 42.31 & 50.33 & 9.53 & 6.70 & 0.14 & 0.10 \\
\hline $\mathrm{L}_{1}$ : lime @ 3 t ha-1 & 17.82 & 46.27 & 52.93 & 11.65 & 6.83 & 0.16 & 0.10 \\
\hline SEm \pm & 0.49 & 0.62 & 0.37 & 0.26 & 0.06 & 0.003 & 0.001 \\
\hline$C D(p=0.05)$ & NS & 3.75 & 2.26 & 1.58 & NS & 0.02 & NS \\
\hline \multicolumn{8}{|l|}{ Sulphur levels } \\
\hline $\mathrm{S}_{0}$ : sulphur @ 0 kg ha-1 & 16.03 & 40.93 & 47.62 & 9.42 & 5.39 & 0.13 & 0.08 \\
\hline $\mathrm{S}_{1}$ : sulphur @ 10 kg ha-1 & 16.82 & 42.55 & 50.23 & 9.85 & 5.80 & 0.14 & 0.09 \\
\hline $\mathrm{S}_{2}:$ sulphur @ 20 kg ha-1 & 17.07 & 44.56 & 51.07 & 10.53 & 6.48 & 0.15 & 0.10 \\
\hline $\mathrm{S}_{3}$ : sulphur @ 30 kg ha-1 & 17.28 & 45.16 & 53.28 & 11.45 & 7.40 & 0.17 & 0.11 \\
\hline $\mathrm{S}_{4}:$ sulphur @ 40 kg ha-1 & 18.81 & 48.24 & 55.96 & 11.71 & 8.76 & 0.18 & 0.13 \\
\hline SEm \pm & 0.71 & 1.30 & 1.41 & 0.23 & 0.12 & 0.004 & 0.004 \\
\hline$C D(p=0.05)$ & NS & 3.89 & 4.22 & 0.69 & 0.35 & 0.01 & 0.01 \\
\hline
\end{tabular}

height at 60 DAS and at harvest. However, plant height at 30 DAS showed no significant effect. Application of lime @ $3 \mathrm{t} \mathrm{ha}^{-1}$ gave highest plant height at 60 DAS $(46.27 \mathrm{~cm})$ and at harvest $(52.93 \mathrm{~cm})$ compared to unlimed condition, while application of sulphur @ $40 \mathrm{~kg} \mathrm{ha}^{-1}$ gave the highest plant height at 60 DAS $(48.24 \mathrm{~cm})$ and at harvest $(55.96 \mathrm{~cm})$ over lower doses of sulphur. The result is in conformity with the findings of Das et al. (2017) and Noman et al. (2015). Crop grow rate on application of lime during the period of 60 DAS to harvest showed no significant variation while the period between 30 DAS to 60 DAS had significant variation. There was also a significant variation in crop growth rate at 30 DAS - 60 DAS and 60 DAS to harvest for sulphur levels as shown in Table 1. On application of lime the highest crop growth rate was recorded between 30 DAS - 60 DAS when the crop was treated with lime @ $3 \mathrm{t} \mathrm{ha}^{-1}\left(11.65 \mathrm{~g} \mathrm{~m}^{-2} \mathrm{~d}^{-1}\right)$ and as for sulphur, application of sulphur level @ $40 \mathrm{~kg} \mathrm{ha}^{-1}$ gave higher CGR (11.71 $\left.\mathrm{g} \mathrm{m}^{-2} \mathrm{~d}^{-1}\right)$ compared to lower doses. The result is in conformity with the findings of Rao et al. (2013). The data in Table 1 also shows that application of lime @ 3 t ha $^{-1}$ recorded highest relative growth rate $\left(0.16 \mathrm{~g} \mathrm{~g}^{-1} \mathrm{~d}^{-1}\right)$ between 30 DAS 60 DAS and as for sulphur, application of sulphur level @ $40 \mathrm{~kg}$ ha ${ }^{-1}$ gave highest RGR $\left(0.18 \mathrm{~g} \mathrm{~g}^{-1} \mathrm{~d}^{-1}\right)$ between 30 DAS - 60 DAS compared to lower doses. The result is in conformity with the findings of Das et al. (2017) and Pancholi (2014). The increase in growth attribute when lime was added may be because liming increases the $\mathrm{pH}$ levels in soil thus increasing alkalinity which provides a source of calcium and magnesium essential for plant growth. As for the increase in growth attribute when sulphur was applied may be because sulphur is essential for nitrogen-fixing nodules on legumes and in the formation of chlorophyll. In the process plants uses the synthesized chlorophyll for producing proteins, amino acids, enzymes and vitamins which aids in growth, and in seed formation.

\subsection{Effect of lime and levels of sulphur on yield attributes and yield of groundnut}

There was significant variation in number of pods plant ${ }^{-1}$, kernel yield $\left(\mathrm{kg} \mathrm{ha}^{-1}\right)$, stover yield $\left(\mathrm{kg} \mathrm{ha}^{-1}\right)$ and harvest index (\%) with the application of lime. The data in table 2 showed that the highest pods plant ${ }^{-1}$ (30.87), kernel yield (1398.14 kg $\left.\mathrm{ha}^{-1}\right)$, stover yield $\left(2865.29 \mathrm{~kg} \mathrm{ha}^{-1}\right)$ and harvest index (39.17\%) was recorded when lime was applied @ $3 \mathrm{t} \mathrm{ha}^{-1}$. The result is in conformity with the findings of Das et al. (2017) and Dey and Nath (2015). The increase in yield attribute when liming was done may be due to the effect of liming which increases the growth attributes of crop due to favorable soil condition and also lime acting as source of $\mathrm{Ca}$ and $\mathrm{Mg}$ essential for plant growth. On application of sulphur there was a significant variation in number of pods plant ${ }^{-1}$, kernel yield $\left(\mathrm{kg} \mathrm{ha}^{-1}\right)$ and stover yield $\left(\mathrm{kg} \mathrm{ha}^{-1}\right)$ whereas harvest index (\%) was found insignificant. The highest pods plant ${ }^{-1}(28.50)$, kernel yield (1160.46 kg ha-1) and stover yield ( $2551.36 \mathrm{~kg} \mathrm{ha}^{-}$ $\left.{ }^{1}\right)$ was recorded when sulphur was applied @ $40 \mathrm{~kg} \mathrm{ha}^{-1}$. The result is in conformity with the findings of Banu et al. (2017) and Sisodiya et al. (2017). The increase in yield attributes on application of sulphur may be because of the favorable effect of sulphur on the growth of groundnut.

\section{Economics}

The data collected on the economics under the effects of lime and levels of sulphur is presented in Table 3 . The highest cost of cultivation ( $₹ 36458.17$ ) was recorded under the treatment $\mathrm{L}_{1} \mathrm{~S}_{4}$ (lime @ $3 \mathrm{t} \mathrm{ha}^{-1}$ and sulphur @ $40 \mathrm{~kg} \mathrm{ha}^{-1}$ ) while the lowest was obtained under $\mathrm{L}_{0} \mathrm{~S}_{0}$ (lime @ $0 \mathrm{t} \mathrm{ha} \mathrm{H}^{-1}$ and sulphur @0 


\begin{tabular}{|c|c|c|c|c|}
\hline Treatments & No. of pods plant ${ }^{-1}$ & Kernel yield $\left(\mathrm{kg} \mathrm{ha}^{-1}\right)$ & Stover yield $\left(\mathrm{kg} \mathrm{ha}^{-1}\right)$ & Harvest Index (\%) \\
\hline \multicolumn{5}{|l|}{ Lime levels } \\
\hline $\mathrm{L}_{0}:$ lime @0 kg ha-1 & 20.27 & 833.56 & 2106.50 & 34.15 \\
\hline $\mathrm{L}_{1}:$ lime @ 3 t ha-1 & 30.87 & 1398.54 & 2865.29 & 39.17 \\
\hline SEm \pm & 0.08 & 7.76 & 20.71 & 0.33 \\
\hline $\operatorname{CD}(p=0.05)$ & 0.50 & 47.22 & 126.00 & 2.02 \\
\hline \multicolumn{5}{|l|}{ Sulphur levels } \\
\hline S: sulphur @ 0 kg ha-1 & 24.17 & 1061.89 & 2381.25 & 36.54 \\
\hline S: sulphur@10 kg ha-1 & 23.67 & 1122.01 & 2483.11 & 36.24 \\
\hline $\mathrm{S}_{2}:$ sulphur@20 kg ha-1 & 24.83 & 1100.05 & 2514.16 & 36.35 \\
\hline S: sulphur@30 kg ha-1 & 26.67 & 1135.85 & 2499.58 & 37.11 \\
\hline S: sulphur@ @ 40 kg ha-1 & 28.50 & 1160.46 & 2551.36 & 37.07 \\
\hline SEm \pm & 0.41 & 14.08 & 20.53 & 0.41 \\
\hline $\mathrm{CD}(p=0.05)$ & 1.22 & 42.21 & 61.54 & NS \\
\hline
\end{tabular}

Table 3: Effect of lime and levels of sulphur on economic parameter of groundnut

\begin{tabular}{lcccc}
\hline Treatments & $\begin{array}{c}\text { Cost of } \\
\text { cultivation } \\
\left(₹ \text { ha }^{-1}\right)\end{array}$ & $\begin{array}{c}\text { total gross } \\
\text { return } \\
\left(₹ \text { ha }^{-1}\right)\end{array}$ & $\begin{array}{c}\text { net return } \\
\left(₹ \text { ha }^{-1}\right)\end{array}$ & $\begin{array}{c}\mathrm{B}: \mathrm{C} \\
\text { ratio }\end{array}$ \\
\hline $\mathrm{L}_{0} \mathrm{~S}_{0}$ & 23658.17 & 51224.08 & 27565.91 & 1.17 \\
$\mathrm{~L}_{0} \mathrm{~S}_{1}$ & 23858.17 & 53502.68 & 29644.51 & 1.24 \\
$\mathrm{~L}_{0} \mathrm{~S}_{2}$ & 24058.17 & 54668.38 & 30610.21 & 1.27 \\
$\mathrm{~L}_{0} \mathrm{~S}_{3}$ & 24258.17 & 56171.4 & 31913.23 & 1.32 \\
$\mathrm{~L}_{0} \mathrm{~S}_{4}$ & 24458.17 & 57098.87 & 32640.69 & 1.33 \\
$\mathrm{~L}_{1} \mathrm{~S}_{0}$ & 35658.17 & 88943.72 & 53285.54 & 1.49 \\
$\mathrm{~L}_{1} \mathrm{~S}_{1}$ & 35858.17 & 90392.72 & 54534.54 & 1.52 \\
$\mathrm{~L}_{1} \mathrm{~S}_{2}$ & 36058.17 & 91702.28 & 55644.11 & 1.54 \\
$\mathrm{~L}_{1} \mathrm{~S}_{3}$ & 36258.17 & 93780.85 & 57522.68 & 1.59 \\
$\mathrm{~L}_{1} \mathrm{~S}_{4}$ & 36458.17 & 96465.47 & 60007.29 & 1.65 \\
\hline
\end{tabular}

$\left.\mathrm{kg} \mathrm{ha}^{-1}\right)$, with $₹ 23658.17$. Highest gross return per hectare ( $₹$ 96465.47) was recorded under the treatment $\mathrm{L}_{1} \mathrm{~S}_{4}$ (lime @ $3 \mathrm{t} \mathrm{ha}^{-1}$ and sulphur @ $40 \mathrm{~kg} \mathrm{ha}^{-1}$ ) while the lowest was obtained under $\mathrm{L}_{0} \mathrm{~S}_{0}$ (lime @ 0 t ha ${ }^{-1}$ and sulphur @ 0 kg ha-1), with ₹ 51224.08. The highest net income (₹ 60007.29) and B: C ratio (1.65) was obtained under treatment $\mathrm{L}_{1} \mathrm{~S}_{4}$ (lime @ $3 \mathrm{t} \mathrm{ha}^{-1}$ and sulphur @ $40 \mathrm{~kg} \mathrm{ha}^{-1}$ ) compared to all the other treatments, lowest net was recorded in $\mathrm{L}_{0} \mathrm{~S}_{0}$ with ₹ 27565.91 having a $\mathrm{B}: \mathrm{C}$ ratio of 1.17 . These results are in conformity with the findings of Dash et al. (2013) where they reported that applying sulphur @ 34 kg ha-1 gave a significantly higher economic in pod yield over lower levels. Dutta and Mondal (2006) observed a $17.19 \%$ of yield increment compared to $100 \%$ RDF alone.

\section{Conclusion}

It has been observed that treatment with lime@ 3 t ha ${ }^{1}+$ sulphur @ 40 kg ha-1 resulted in highest kernel and stover yield with net return (₹ 60007.29) and BC ratio (1.65) followed by liming @ 3 t ha ${ }^{-1}+$ sulphur @ 30 kg ha ${ }^{-1}$ with net return (₹ 57522.68) and BC ratio (1.59). Thus it can be concluded that liming @ 3 t ha ${ }^{-1}$ along with sulphur @ 40 kg ha-1 along with recommended dose of NPK (20:60:40) gave best result for the growth and yield of groundnut.

\section{References}

Banu, R., Shroff, J.C., Shah, S.N., 2017. Effect of sources and levels of sulphur and bio-fertilizer on growth, yield and quality of summer groundnut. International Journal of Agricultural Sciences 13(1), 67-70.

Dai, Z., Zhang, X., Tang, C., Muhammad, N., Wu, J., Brookes, P.C., Xu, J., 2017. Potential role of biochars in decreasing soil acidification-a critical review. Science of the Total Environment 581-582, 601-611.

Das, S., Das, A., Idapuganti, R., Layek, J., Chowdhury, S., 2017. growth and physiology of groundnut as influenced by micronutrients and liming in acid soil of North East India. Indian Journal of Hill Farming 29, 40-47.

Dash, A.K., Nayak, B.R., Panigrahy, N., Mohapatra, S., Samant, P.K., 2013. Performance of groundnut (Arachis hypogaea) under different levels of sulphur and irrigation. Indian Journal of Agronomy 58(4), 578-582.

Dey, D., Nath, D., 2015. Assessment of effect of liming and integrated nutrient management on groundnut under acidic soil condition of West Tripura. An Asian Journal of Soil Science 10(1), 149-153.

Dutta, D., Mondal, S.S., 2006. Response of summer groundnut (Arachis hypogaea L.) to moisture stress, organic manure 
and fertilizer with and without gypsum under lateritic soil of West Bengal. Indian Journal of Agronomy 51(2), 145-148.

Fageria, N.K., Nascente, A.S., 2014. Management of soil acidity of South American soils for sustainable crop production. Advances in Agronomy 128, 221-275.

Gascho, G.J., Hodges, S.C., Alva, A.K., Csinos, A.S., Mullinex Jr., B.G., 1993. Calcium and time of application for runner and virginia peanut. Peanut Science 20(1), 31-35.

Gomez, K.A., Gomez, A.A., 1984. Statistical procedures for agricultural research (2 ed.). John wiley and sons, New York, 680.

Haynes, R.J., 1984. Lime and phosphate in the soil-plant system. Advances in Agronomy 37, 249-315.

Jaggi, R.C., 2004. Effect of sulphur levels and sources on composition and yield of onion. Indian Journal of Agricultural Sciences 74(4), 219-220.

Kumar, M., Khan, M.H., Singh, P., Ngachan, S.V., Rajkhowa, D.J., Kumar, A., Devi, M.H., 2012. Variable lime requirement based on differences in organic matter content of iso-acidic soils. Indian Journal of Hill Farming 25(1), 26-30.

Mandal, S.C., 1997. Introduction and historical overview. In: Mahapatra, I.C., Mandal, S.C., Misra, C., Mitra, G.N., Panda, N. (Eds.), Acidic Soils of India ICAR, New Delhi, 3-24.

McLaren, R.G., Cameron, K.C., 1996. Soil science sustainable production and environmental protection. Oxford University Press.

Najar, G.R., Singh, S.R., Akthar, F., Hakeem, S.A., 2011. Influence of sulphur levels on yield, uptake and quality of soybean (Glycine max) under temperate conditions of Kashmir valley. Indian Journal of Agricultural Sciences 81(4), 340-343.

Noman, H.M., Rana, D.S., Rana, K.S., 2015. Influence of sulphur and zinc levels and zinc solubilizer on productivity, economics and nutrient uptake in groundnut (Arachis hypogaea L.). Indian Journal of Agronomy 60(2), 301-306.
Anjum, N.A., Gill, S.S., Umar, S., Ahmad, I., Duarte, A.C., Pereira, E., 2012. Improving growth and productivity of Oliferous brassica under changing environment. Significance of nitrogen and sulphur nutrient and underlying mechanisms. The Scientific World Journal, 12.

Panwar, A.S., Singh, N.P., Saxena, D.C., Munda, G.C., 2003. Agricultural status and cropping systems in $\mathrm{NEH}$ region. In: Bhatt, B.P., Bujarbaruah, K.M., Sharma, Y.P., Patiram, (Eds.), Proceedings approaches for increasing agricultural productivity in hill and mountain ecosystem. ICAR Research Complex for NEH Region, Umiam, Meghalaya, 191-195.

Rao, K.T., Rao, A.U., Sekhar, D., 2013. Effect of sources and levels of sulphur on groundnut. Journal of Academia and Industrial Research 2(5), 268-270.

Sharma. U.C., Singh, R.P., 2002. Acid soils of India: their distribution, management and future strategies for higher productivity. Fertilizer News 47(3), 45-52.

Singh, L.A., 1999. Mineral Nutrition of Groundnut. Scientific Publishers, India 2, 161-200.

Singh, R.A., 2007. Effect of variable doses of potassium, sulphur and calcium on pod yield of short duration summer groundnut (Arachis hypogaea L.). International Journal of Agricultural Sciences 3(1), 196-198.

Smil, V., 2002. Nitrogen and food production: proteins for human diets. Ambio 31(2), 126-131.

Sisodiya, R.R., Babaria, N.B., Parmar, T.N., Parmar, K.B., 2017. Effect of sources and levels of sulphur on yield and micronutrient ( $\mathrm{Fe}, \mathrm{Mn}, \mathrm{Zn}$ and $\mathrm{Cu}$ ) Absorption by groundnut (Arachis hypogaea L.). International Journal of Agriculture Sciences 9(32), 4465-4467.

Sumner, M., Noble, A., 2003. Soil acidification: The world story, In: Rengel, Z. (Ed.), Handbook of soil acidity. Marcel Dekker, New York, 1-28

Tandon, H.L.S., Messick, D.L., 2002. Practical sulphur guide. The Sulphur Institute, Washington, D.C. 